\title{
New Disease Reports \\ First report of Diaphorthe masirevicii causing leaf blight of Gloriosa superba in India
}

\author{
J. Naveen ${ }^{1}$, H.M. Navya ${ }^{1}$, G. Hithamani ${ }^{2}$, S.R. Niranjana ${ }^{1}$ and P. Hariprasad ${ }^{3 *}$ \\ ${ }^{1}$ Department of Studies in Biotechnology, University of Mysore, Manasagangotri, Mysore 570 006, Karnataka, India; ${ }^{2}$ \\ CSIR-Central Food Technological Research Institute, Mysore 570020; ${ }^{3}$ Centre for Rural Development and Technology, \\ Indian Institute of Technology, Delhi, Hauz Khas, New Delhi 110016
}

*E-mail: phari@iitd.ac.in

Received: 29 Sep 2017. Published: 02 Mar 2018.

Gloriosa superba (Glory lily, Colchicaceae) is an endangered perennial climbing herb, grown in Africa and Asia for its medicinal properties (Jain \& Suryavanshi, 2010). A leaf blight disease (Fig. 1) was observed during surveys performed in the region of Mysore, India. The first symptoms of infection were small (2-5 $\mathrm{mm}$ diameter), circular to oval, light brownish spots, surrounded by a yellow halo. Leaf spots occured on the leaf tips, margins and midribs of the leaves, enlarging to form spots with concentric rings. Embedded in the necrotic tissues were black fruiting bodies of a fungus. These symptoms also appeared later on the stem.

Infected leaves were surface sterilised with $70 \%$ ethanol followed by three washes with sterile distilled water and incubated for seven days on moist blotter discs. After incubation, colony development was examined and the fungus isolated and maintained on potato dextrose agar (PDA). The fungus was identified based on its colony type, morphology and production of pycnidial ooze (Fig. 2). Pycnidiospores were produced in slimy masses and were of two types, alpha and beta. Alpha conidia were fusoid to ellipsoidal and biguttulate, while beta conidia were filiform, slightly curved and rarely straight (Fig. 3). The morphological characters of the fungus were compared with the description of Thompson et al. (2015) and identified as Diaphorthe sp. Fungal DNA was extracted from mycelium following standard procedures (Saitho et al., 2006). The fungus was identified by amplifying and sequencing the internal transcribed spacer (ITS), $\beta$-tubulin and transition elongation factor (TEF) regions using specific primers (Table 1). BLAST analysis revealed identities of $99 \%$ for ITS, $99 \%$ for $\beta$-tubulin and $100 \%$ for TEF to D. masirevicii isolate 054 (GenBank Accession No. KR024727), D. masirevicii isolate BRIP 57892a (KJ197257) and $D$. masirevicii isolate BRIP 54120a (KJ197243), respectively. These sequences were submitted to GenBank (ITS: MF682435, $\beta$-tubulin: MF668289 and TEF: MF668290).

Pathogenicity tests were conducted using a detached leaf assay $(n=25)$ and whole plant assay $(\mathrm{n}=10)$, under greenhouse conditions $\left(22-28^{\circ} \mathrm{C}\right.$ and under natural light). A suspension of alpha conidia was prepared by flooding 18 to 21-day-old PDA cultures with sterile distilled water and adjusting the spore concentration to $1 \times 10^{6}$ conidia/ml. Detached healthy and surfacesterilised leaves were wounded by pricking with a sterile needle, and $10 \mu \mathrm{l}$ of conidial suspension placed onto the wound site. Wounded control leaves received only distilled water. The leaves were incubated in a moist chamber at $28 \pm 2{ }^{\circ} \mathrm{C}$ for three-seven days. The appearance of water-soaked lesions and brown spots on inoculated leaves confirmed pathogenicity (Fig. 4). The whole plant assay was conducted using three-month-old plants. Plants were spray inoculated with either a suspension of $1 \times 10^{6}$ conidia $/ \mathrm{ml}$, or water as a control and observed for symptoms for the next thirty days. The pathogen was reisolated from infected leaves showing typical symptoms, thus fulfilling Koch postulates.

As per our knowledge and from a literature survey, this is the first report of Diaphorthe masirevicii causing leaf blight of Gloriosa superba in India.

\section{References}

Jain AP, Suryavanshi S, 2010. Gloriosa superba Linn. - A pharmacological review. International Journal of Pharma Research and Development 2, 24-26.

Saitoh K-I, Togashi K, Arie T, Teraoka T, 2006. A simple method for a mini-preparation of fungal DNA. Journal of General Plant Pathology 72, 348-350. http://dx.doi.org/10.1007/s10327-006-0300-1

Thompson SM, Tan YP, Shivas RG, Neate SM, Morin L, Bissett A, Aitken EAB, 2015. Green and brown bridges between weeds and crops reveal novel Diaporthe species in Australia. Persoonia: Molecular Phylogeny and Evolution of Fungi 35, 39-49. http://dx.doi.org/10.3767/003158515X687506

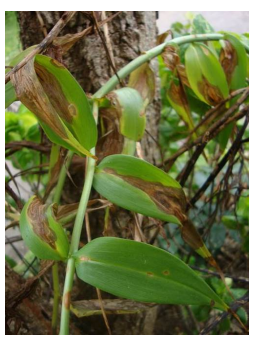

Figure 1

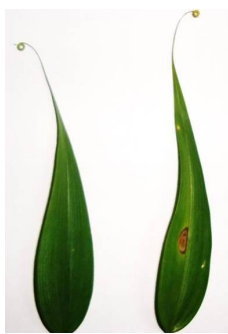

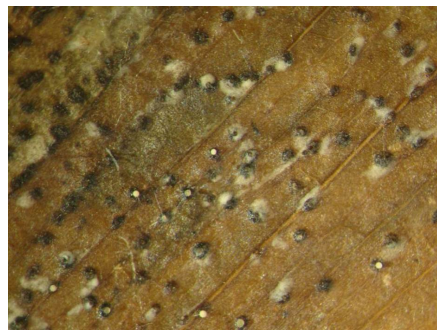

Figure 2 Table 1. Ping

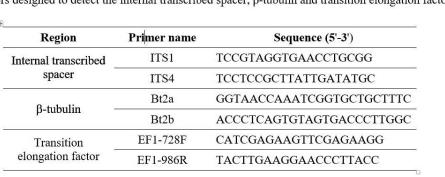

Figure 5

Figure 4

To cite this report: Naveen J, Navya HM, Hithamani G, Niranjana SR, Hariprasad P, 2018. First report of Diaphorthe masirevicii causing leaf blight of Gloriosa superba in India. New Disease Reports 37, 13. http://dx.doi.org/10.5197/j.2044-0588.2018.037.013

(c) 2018 The Authors

This report was published on-line at www.ndrs.org.uk where high quality versions of the figures can be found. 